\title{
Valorisation of Natural Waste: Dam Sludge for Road Construction
}

\author{
A. Larouci*, Y. Senhadji*, L. Laoufi *† and A. Benazzouk** \\ *University of Mascara, Faculty of Science and Technology, Department of Civil Engineering, Mascara, Algeria \\ ** Department of Civil Engineering, University of Picardie Jules Verne, Amiens, France \\ $†$ Corresponding author: L. Laoufi; laoufifr@yahoo.fr; 1.laoufi@univ-mascara.dz
}

Nat. Env. \& Poll. Tech.

Website: www.neptjournal.com

Received: 29-01-2020

Revised: 26-02-2020

Accepted: 16-04-2020

Key Words:

Dam sediment

Valorisation

Lime treatment

CBR

Natural waste

\begin{abstract}
The Algerian dams are in a more or less silted state. Fergoug dam is the most silted dam since it records a rate of siltation of $95 \%$. The siltation of the dam is undoubtedly the most dramatic consequence of the problem of erosion in Algeria. The investigations are at two levels: either prevent the solids to arrive in the dam (that is to put obstacles to break the forces of the runoff water, but we can only hope partial results) or the evacuation of sediments by appropriate management of bottom. But in our opinion, their valorisation in the field of construction is the most appropriate solution. This valorisation helps protect the environment and natural materials. Many mud treatment methods are often used to improve the insufficient geotechnical properties before reuse for a certain function in the structure. Lime treatment is one of the most common methods of converting soils to new materials that provide the desired performances. The objective of this work is to study the mud behaviour of the Fergoug dam (Algeria) for its use in the application of road engineering. The study consists of reconstituting samples of the Fergoug dam mud with various proportions of lime in the laboratory and subjecting them to various tests (Proctor, VBS, CBR index, DRX, etc.). The results obtained are encouraging and therefore allow the valorisation of sediments of the Fergoug dam which are a cumbersome waste for the environment.
\end{abstract}

\section{INTRODUCTION}

The management of the dredged material generated by this activity is confronted with legal, financial, environmental, technical and scientific difficulties. The solidification/stabilization technique based on hydraulic binders and/or aerial is used to valorise and reuse the treated dredging sediments. This technique will make it possible to find economic and environmental solutions to dredged sediments from dams, based on scientific and technical work. The treatment with hydraulic binders is preferential for valorisation in road techniques (underlayment or embankments).

The results of the sediment recovery study thus treated show that the mechanical performances (threshold of $1 \mathrm{MPa}$ required for the simple compressive strength at 28 days) associated with an environmental and economic approach are achieved with several combinations of pre-treatment and treatment (Sannier et al. 2009, Levacher et al. 2011).

The methodology of valorisation of sediments as road material (more particularly in the form layer) is based on the recommendations of the LCPC-SETRA technical guides for road earthworks and soil treatment with lime and hydraulic binders (GTR 2000).

The results analysed here are related to sediment treatment of dam Fergoug (Algeria) and they will be studied in terms of processability. The dam of Fergoug offers a distressing view due to its sedimentation rate, estimated at $95 \%$. The initial storage capacity of this dam was 17 million $\mathrm{m}^{3}$. In 2005, it underwent a dredging operation which allowed recovering 10 million cubic meters of sediments. Therefore, because of these huge quantities, the valorisation of these dredged sediments remains a real challenge (Laoufi et al. 2016, Larouci et al. 2018). The dredging operation is an important phase in the recovery and preservation of useful storage volumes of dams. But the fate of the large quantities of sediment recovered is a major environmental and economic challenge (Levacher et al. 2006).

The mechanical behaviour will be analysed to identify trends and correlations between the geotechnical properties of a side and treat the ability of binders and thus enhance the value of sediment of another side.

The tests include measurements of unconfined compressive strengths (UCS). The results obtained show that the sediments of Fergoug dam do not reach the mechanical performance required by the geotechnical and safety works (GTS).

\section{MATERIALS AND METHODS}

\section{Sediment Sampling}

Sediment samples were collected at the Fergoug dam. This dam is located $20 \mathrm{~km}$ upstream from Mohamadia on the road 
to Mascara city (RN17) in the north-west of Algeria Fig.1. It was built upon the installation of the first settlers in Oran city, during the last century. Fergoug dam is a dam in the earth having in 1963 a capacity of 18 million $\mathrm{m}^{3}$. The filling rate of the Fergoug dam was 95\% in 2019 (ANBT 2014). To ensure an acceptable level of service, the dam authorities regularly dredged it during the period from 1986 to 1989 generating very large volumes of material $\left(10\right.$ million $\mathrm{m}^{3}$ of silt were extracted) (Semcha 2006).

Deposited downstream in grossly developed areas, the dredged mud is again eroded to the mouth of the Macta wadi. Sediment samples were collected from three different sites downstream of the Fergoug Dam. All sampled sediments were transported to the laboratory and homogenized to obtain raw sediments; these were stored in airtight containers.

\section{Granular Corrector Sampling}

In this study, an aerial binder was used to formulate road materials containing quantities of dredged sediment. This aerial binder was mainly composed of lime. It is a natural tuff which was extracted from a quarry located in Douar Sidi Ali Cherif (Mascara, Algeria). The characteristics of this Sidi Ali Cherif tuff (SCT) are given in Table 1. According to this table, we can say that the tuff is loamy soil, weakly plastic and rich in fine elements. It is therefore finally a sandy and gravelly soil rich in fine elements.

Organic matter has some undesirable characteristics in road construction because of its swelling structure. The Fer- goug dam sediments (FDS) have a significant organic matter content of $3.15 \%$ versus a value of $0.31 \%$ for Sidi Ali Cherif Tuff (SCT). These values can have a significant impact on the geotechnical and mechanical behaviour of sediments.

Organic materials can also have an impact on binder hydration. For our study, the rate of silt used was incorporated which neglects the risk of the negative effect of organic matter. The organic material test was carried out on a fraction by weight of $0 / 2 \mathrm{~mm}$ at $450^{\circ} \mathrm{C}$ during 3 hours. In addition, it will be possible to use these values to classify different sediments according to the French Guide to Road earthworks (GTR 2000).

\section{RESULTS AND DISCUSSION}

\section{The Limits of Atterberg}

The Figs. 2, 3 and 4 show LL, PL, PI as a function of lime added $(0,2,4,6$ and $8 \%)$ for 10, 20 and $30 \%$ of FDS. As we see for these three figures, more the percentage of lime increases more LL and PI decrease. As for PL, it increases with the increase in the percentage of lime.

The addition of lime leads to an improvement in the consistency because of a significant reduction of the plasticity index which results in an increase in the limit of plasticity accompanied by a decrease of the limit of liquidity. Thus, the specific surface is reduced immediately after the incorporation of the lime at the end of the clays flocculation. These results have been confirmed by many researchers. Guney et

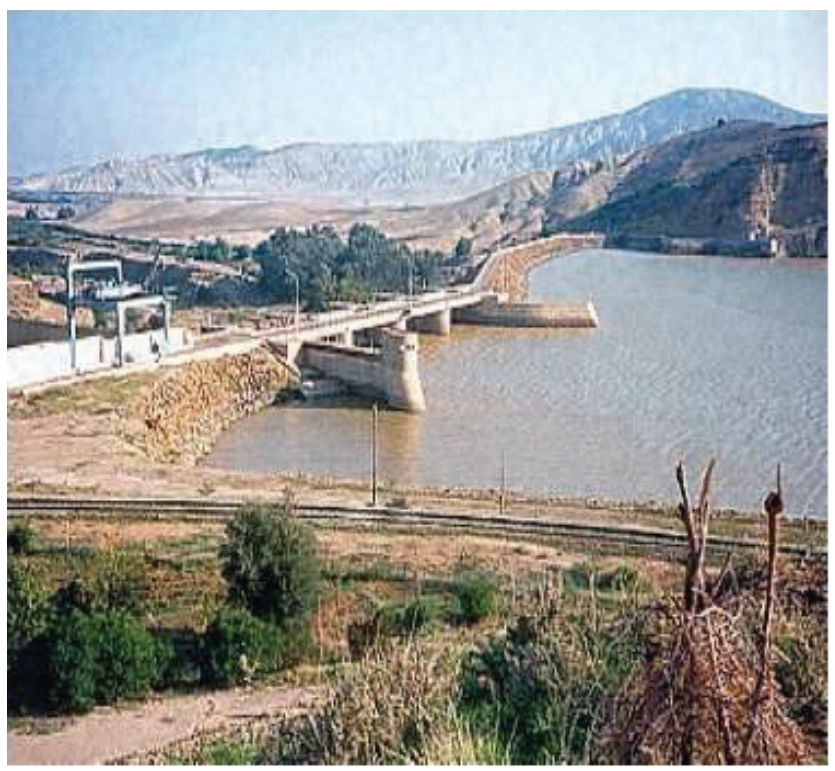

Fig. 1: Fergoug dam (Algeria). 
Table 1: Geotechnico-physical characteristics of SCT and FDS.

\begin{tabular}{|llll|}
\hline Characteristics & Designation & FDS & SCT \\
\hline Natural water content & $\mathrm{Wn}(\%)$ & 58,10 & 8,34 \\
Liquid limit & $\mathrm{LL}(\%)$ & 62,54 & 25,19 \\
Plastic Limit & $\mathrm{PL}(\%)$ & 29,29 & 15,87 \\
Plasticity index & $\mathrm{PI}(\%)$ & 33,26 & 9,32 \\
Dry density & $\gamma_{\text {max }}\left(\mathrm{g} / \mathrm{cm}^{3}\right)$ & 1,779 & 1,985 \\
Optimum water content & $\mathrm{W}_{\text {opt }}(\%)$ & 19,30 & 10,97 \\
Methylene blue value & $\mathrm{MBV}(\%)$ & 3,42 & 0,66 \\
Carbonates & $\mathrm{CaCO}(\%)$ & 27,94 & 88,70 \\
Organic material & $\mathrm{OM}(\%)$ & 3,15 & 0,31 \\
Fine elements $<80 \mu \mathrm{m}$ & $\mathrm{FE}(\%)$ & 17.77 & - \\
\hline
\end{tabular}

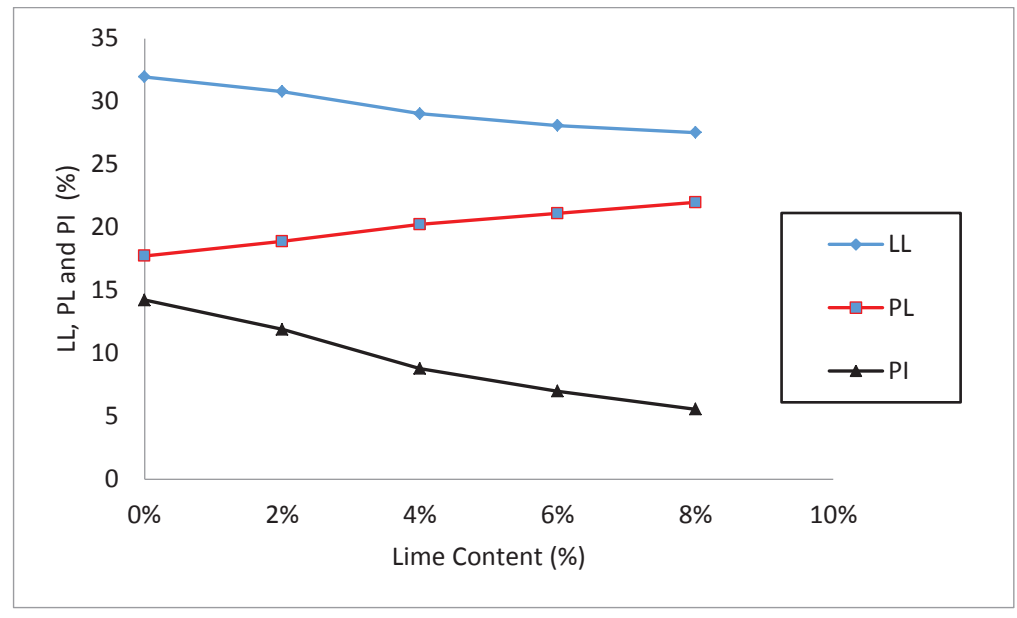

Fig. 2: 10\% FDS treated with 0, 2, 4, 6 and $8 \%$ lime.

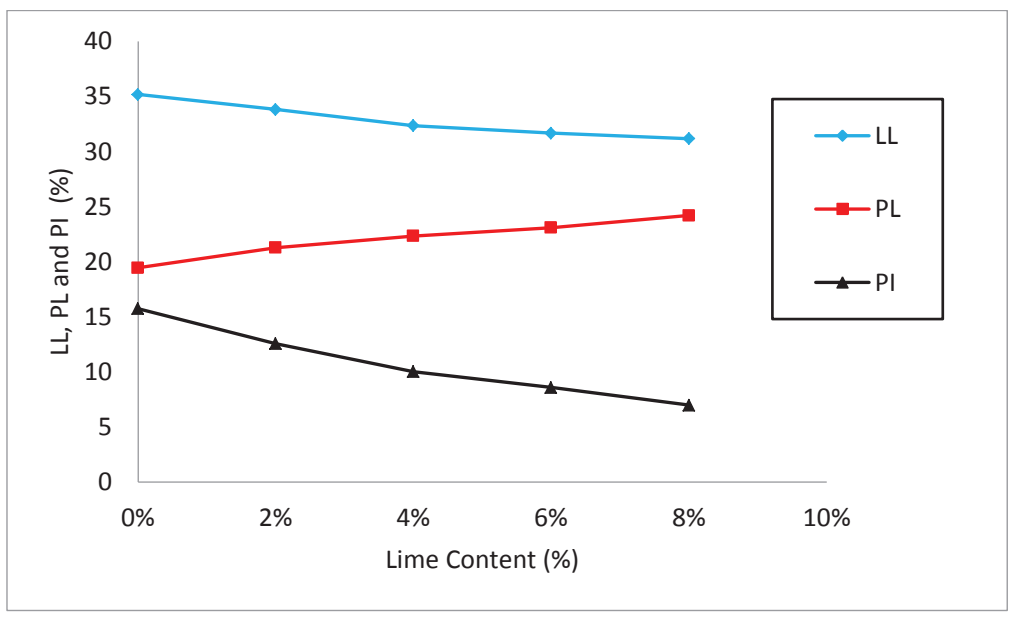

Fig. 3: 20\% FDS treated with 0, 2, 4, 6 and 8\% lime. 
al. (2007), Manassah \& Olufemi (2008) who have worked on similar themes demonstrated in their investigations that the liquid limit (LL) varies according to the lime mix and the nature of the clay soil treated, with respect to the plastic limit (PL) large increase was still observed. George et al. (1992) concluded in their study that the soil plasticity index decreased with the addition of lime and this decrease was related with the increase of the plasticity limit rather than the decrease of the liquidity limit.

\section{Methylene Blue Value (MBV)}

For each sediment and lime content, we measured the methylene blue value (Fig. 5). The results of the blends are illustrated in the graph of Fig. 5. The increase of the lime content caused a decrease of the MBV and consequently the specific surface area of the mixture treated (SCT $+\%$ FDS) decreased. This decrease was remarkable for an addition of $2 \%$ lime content for all mixtures, then it was less accented for the other percentages (4, 6 and $8 \%$ ). Hydrates resulting from the pozzolanic reaction have coated the surface of the soil particles and have acted as binders between the particles. This has reduced the surface area of the clay particles and hence the methylene blue value.

\section{Compaction Tests (Modified Proctor)}

The compaction characteristics depend on three parameters, the grain size distribution, the soil specific gravity and stabilizing mineral additions. These stabilizers initially

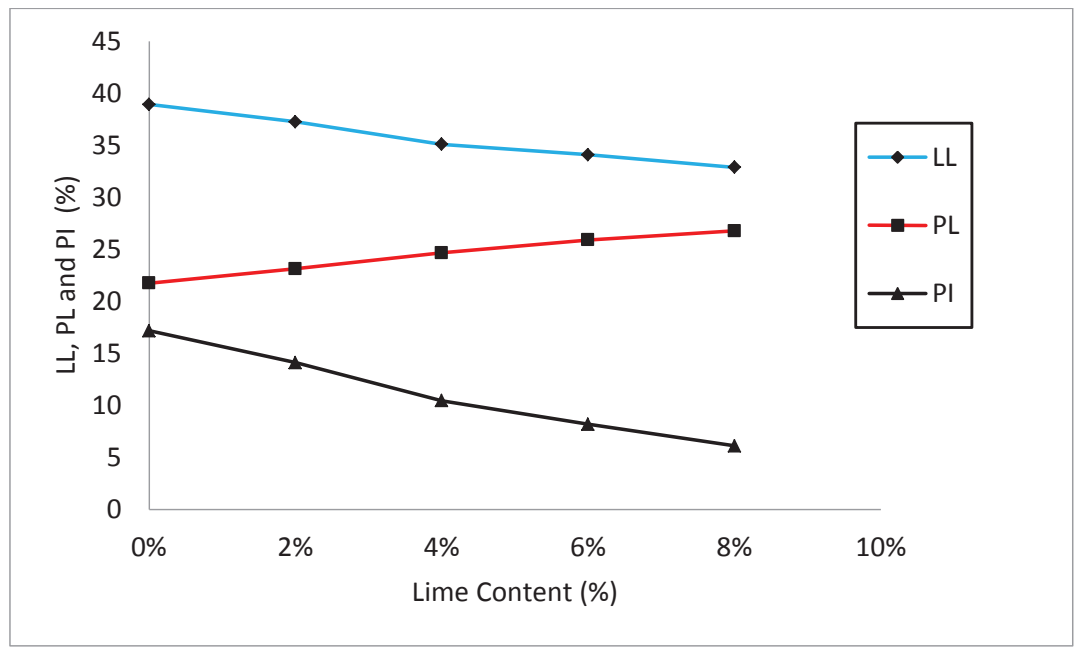

Fig. 4: 30\% FDS treated with 0, 2, 4, 6 and $8 \%$ lime.

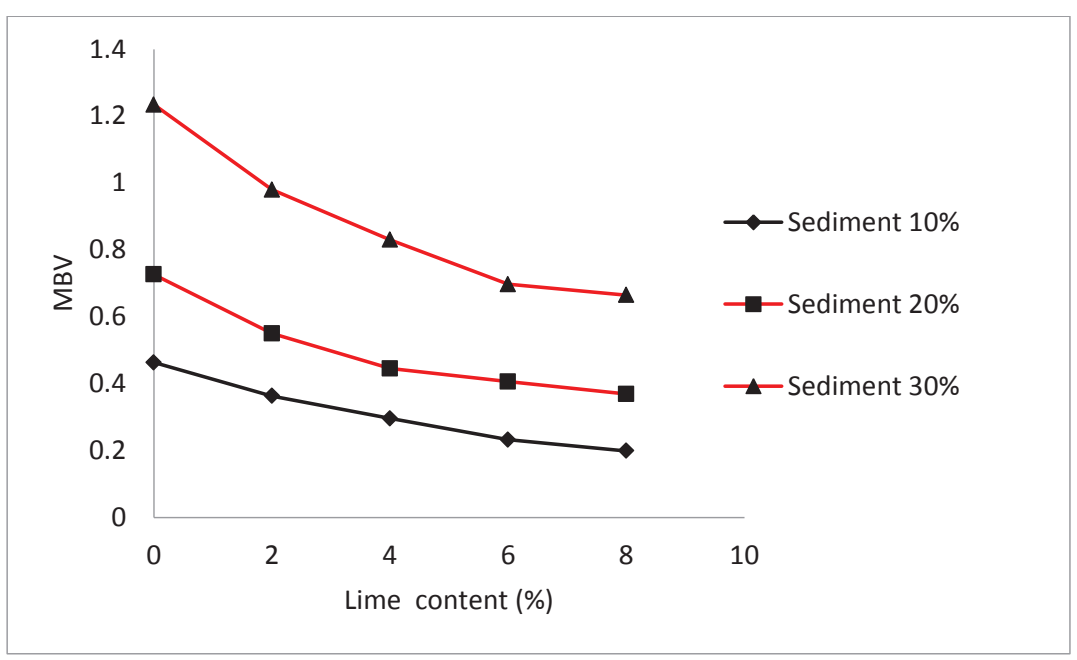

Fig. 5: The evolution of the methylene blue value as a function of the lime content. 
react with the soil to form large aggregates and so occupy a large space. However, soil fine particles tend to decrease dry density and the stabilizers (which tend to increase dry density) offset larger.

The lime treatment of the mixtures, as we see in Figs. 6, 7 and 8 , reduces the maximum value of the dry density more and more and increases the value of the optimal moisture content (GTS 2000). The increase in the optimum water content was due to the increase of the total particle surface of the mixtures treated by the fine grains of the added lime. The reason for the decrease in the maximum dry density was the low density of the lime contained in the mixture. These results confirm the results of the researchers Kavak \&
Akyarh (2007) and Hossain et al. (2007) who explained that the reduction in maximum dry density was due firstly to the formation of aggregate particles so that they will occupy a large space and therefore to the graduation of soils. Second, the specific density of lime was lower than the specific gravity of the lateral soil, which has been confirmed by Ola (1977). Third, increasing the optimal water content with increasing the lime was due to the additional water required for pozzolanic reactions, the result confirmed by the researchers Manassah \& Olufmi (2008). Another remark is the shape of compaction curves treated with lime compared to others, they take a flattened shape, which explains the insensitivity to the water of these mixtures. These results have been confirmed by the researchers (Mellal 2010).

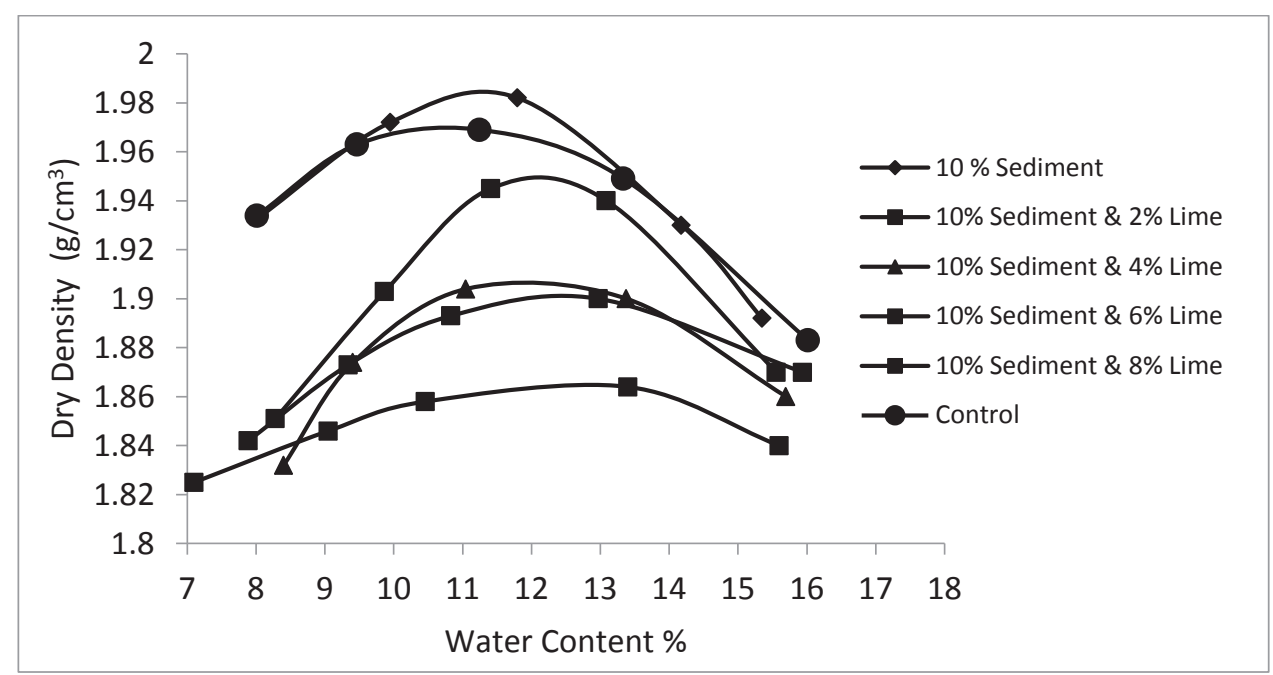

Fig. 6: Evolution of the maximum dry density of (SCT $+10 \% \mathrm{FDS})+2,4,6$ and $8 \%$ of the lime as a function of the water content.

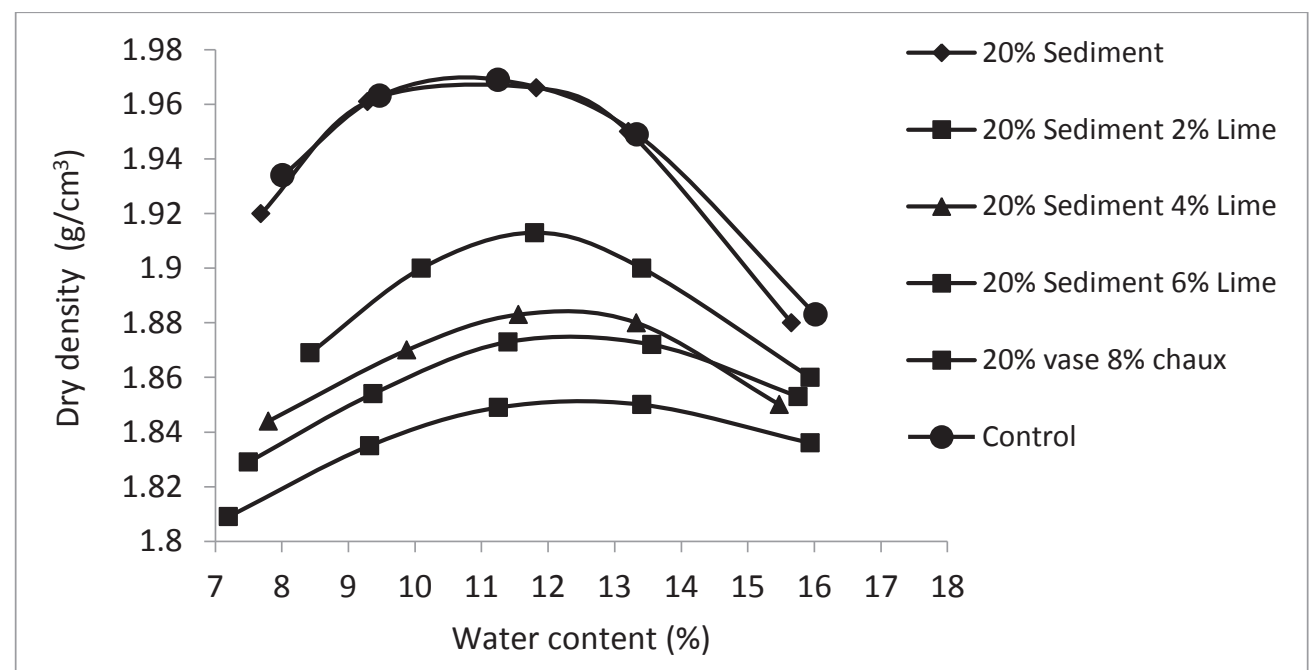

Fig. 7: Evolution of the maximum dry density of (SCT $+20 \%$ FDS $)+2,4,6$ and $8 \%$ of the lime according to the water content. 


\section{Lift Tests (CBR After Immersion)}

As we see in Fig. 9, the addition of sediment significantly reduced the CBR index of the mixture (SCT + FDS), it was $68.9,66.6$ and $32.9 \%$ for road aggregates and the additions of 10 and $30 \%$ of sediments respectively. Vat in the wet state (immersion) even in small proportion can affect the lift of the mixtures (Larouci et al. 2018). Indeed, the wet sediment has a very low punching resistance. The grains surrounded by sediment easily avoid the pressures generated by the cylinder of the punching apparatus moving towards the points of low pressures; these displacements are more and more favoured by the addition of sediment.

This action occurs between the lime and the clay minerals present in the added sediment when their proportion is significant (Larouci et al. 2017). The principle of pozzolanic reaction is based on the possibility, in high $\mathrm{pH}$ medium (greater than

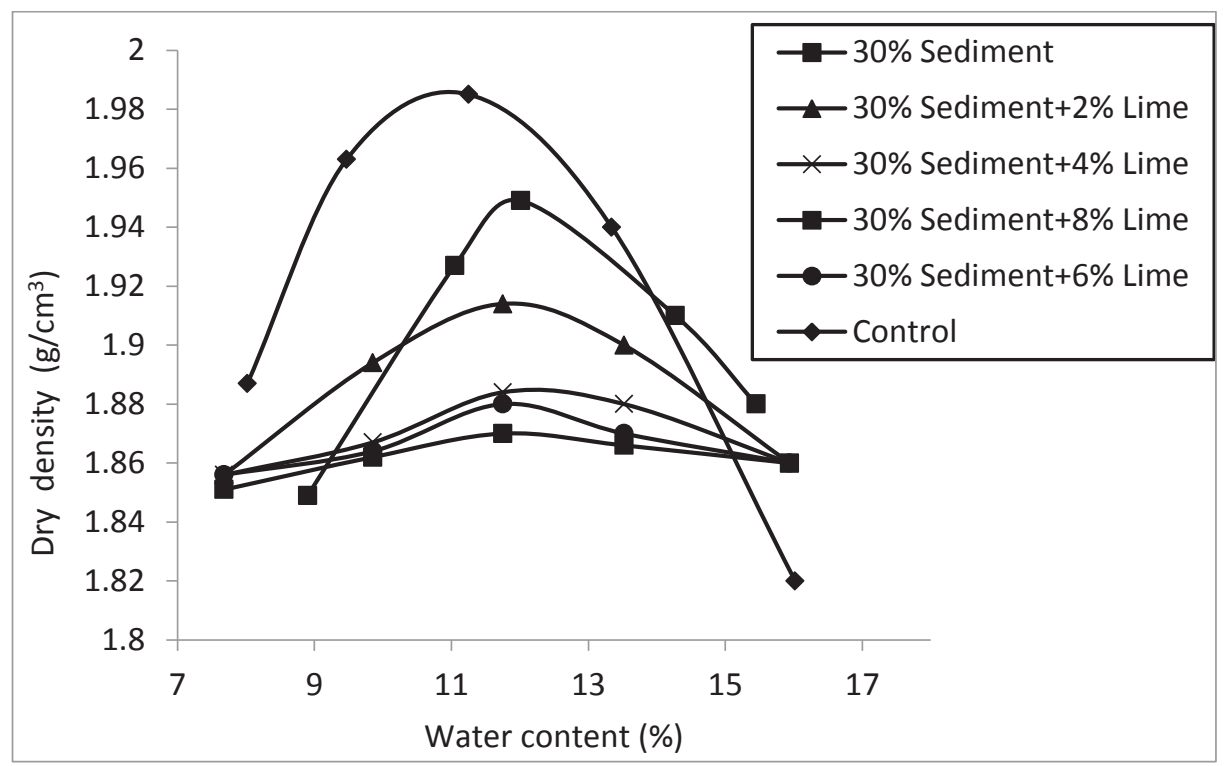

Fig. 8: Evolution of the maximum dry density of (SCT $+30 \% \mathrm{FDS})+2,4,6$ and $8 \%$ of the lime as a function of the water content.

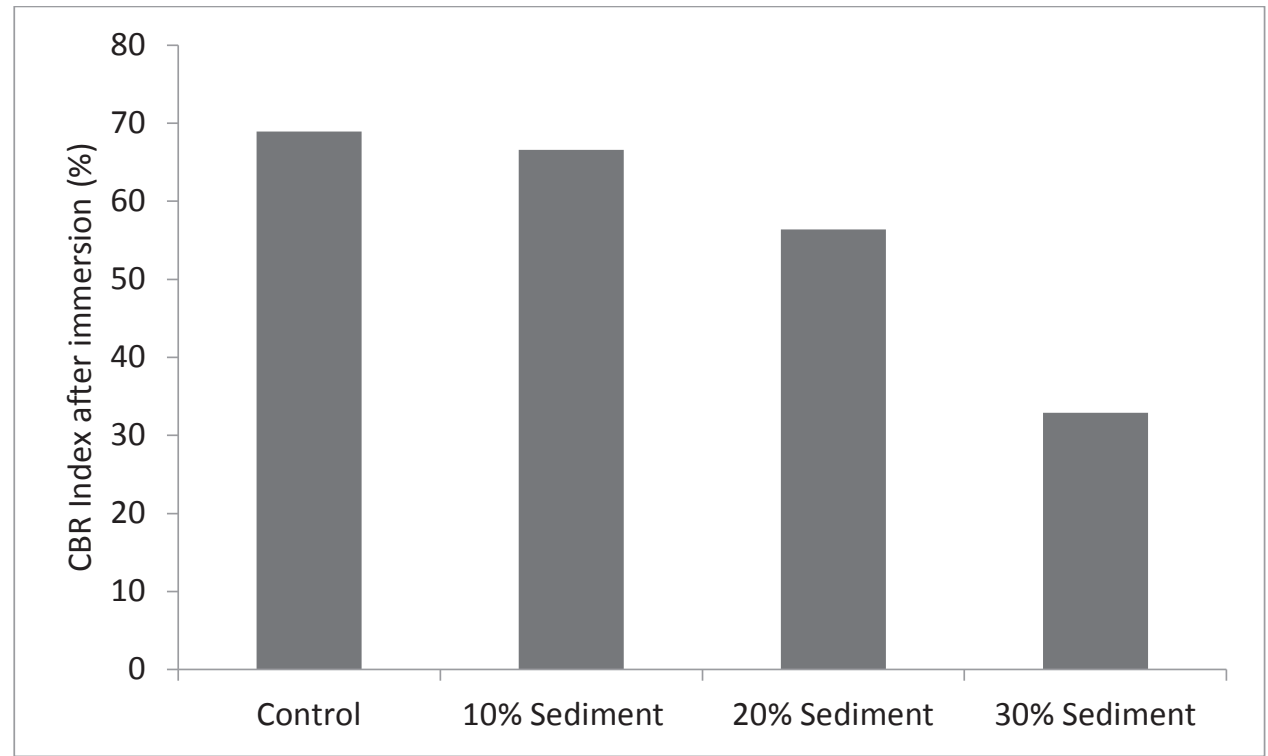

Fig. 9: Evolution of the CBR index after immersion as a function of the sediment content (before treatment). 
12), of dissolution of silica, alumina, iron oxides present in clay minerals under crystallized forms more or less altered.

These elements in solution then react with lime to form insoluble lime ferro-silicoaluminates which precipitate and crystallize in the presence of water thus creating bonds of the same nature as those produced with hydraulic binders according to GTS (2000).

The manifestation of this action is shown in Fig. 10 by the increase of the CBR index after 4 days of immersion. In this case, after the lime treatment, we notice a strong increase of CBR index for all the mixtures (sediment + lime).
The decrease in the CBR index for the proportion of $30 \%$ of sediment treated with $2 \%$ of the lime is due to the proportion of clay minerals exaggerated in relation to the lime content.

\section{Unconfined Compressive Strength (UCS)}

Fig. 11 shows the results of the mechanical strength of the tested samples. The UCS was measured at the age of 28 days. The UCS decreased from the first addition of FDS despite the addition of $10 \%$ DFS at a higher dry density than the other additions. This decreased the low lift of FDS, the grains of FDS present between the grains of SCT undergo low friction generated by the pressure of the device.

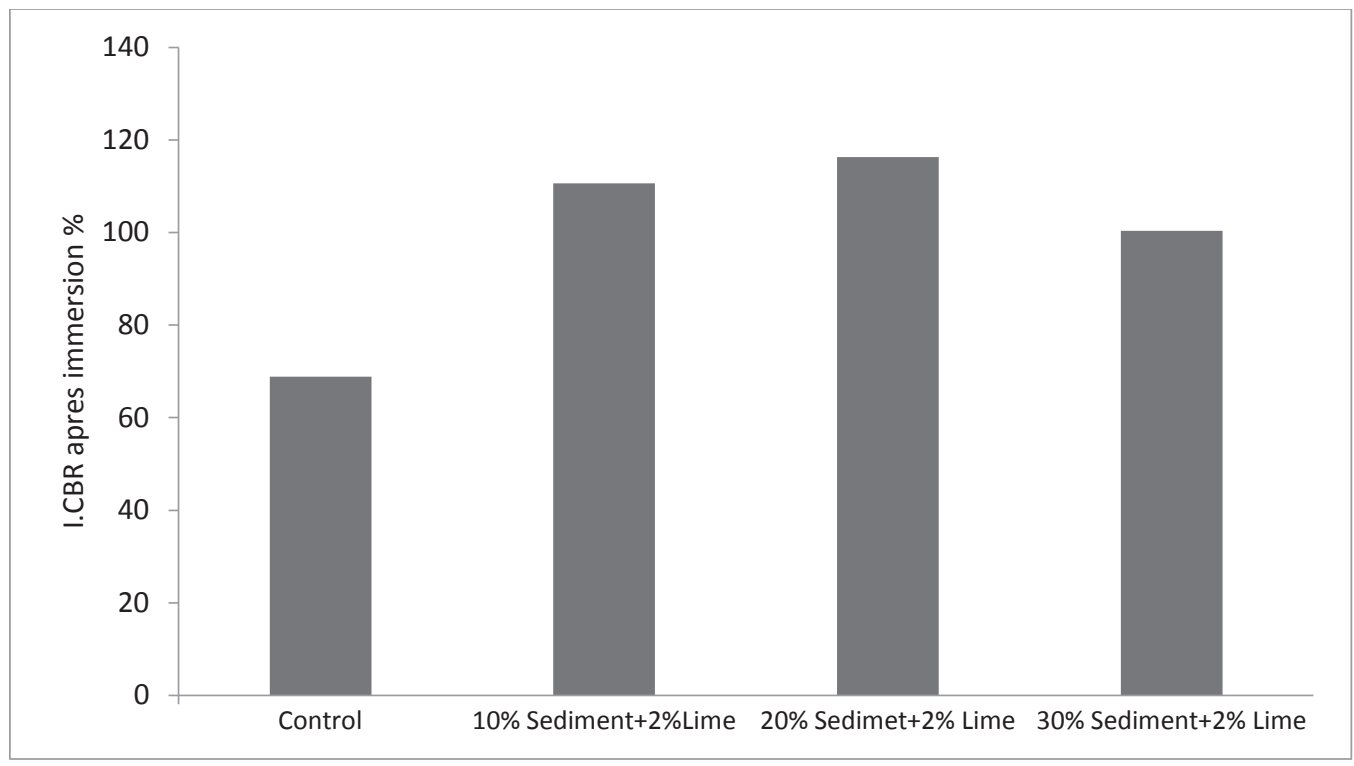

Fig. 10: Evolution of the CBR index after immersion as a function of the sediment content (after treatment).

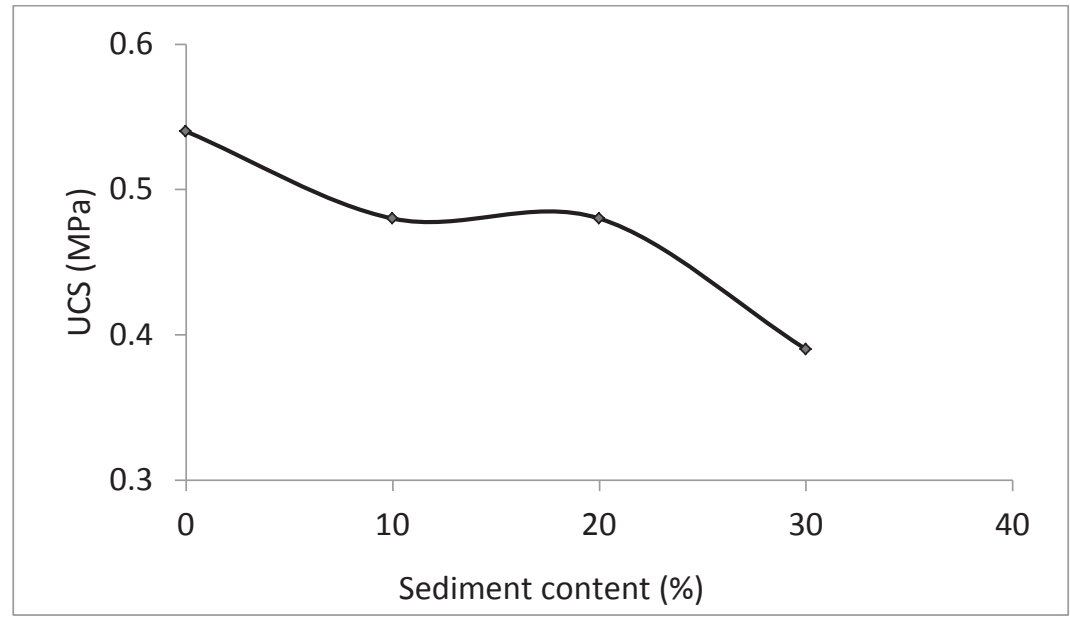

Fig. 11: Evolution of the UCS as a function of the sediment content (before treatment). 
Fig. 12 shows the results of the mechanical strength of the test samples. The UCS of lime samples is higher than samples containing SCT + \% FDS alone. Compression resistance increased from 0.48 to $1.11 \mathrm{MPa}$ for a treatment of $10 \%$ FDS + $2 \%$ lime and from 0.48 to 1.67 for a $10 \%$ addition of FDS $+2 \%$ lime. It can be seen that the proportion of $20 \%$ FDS $+2 \%$ lime in a mixture can improve the strength to $150 \%$ of the mixture.

The immediate reaction of clay soil with mineral additions caused modifications in the rheological behaviour of the treated soils due to the phenomenon of flocculation causing a change in particle size by aggregation (Sakr et al. 2008, Okagbue \& Ochulor 2007, Ansary et al. 2006) and inducing an improvement in the properties of treated soils. Even if the optimum of compaction is shifted to higher water contents and if compacting density is lower, the mechanical properties improve with the treatment of mineral additions (Osinubi 2006, Guney et al. 2007). According to Bell (1996), the mechanical strength of clay soils increases with the lime addition which is consistent with the results of Attoh-Okine (1995).

Bell (1996) noted that compressive resistance depends on the presence of pozzolan. When the pozzolan is available, it reacts with lime and this improves the compressive resistance. It would prove than the absolute amount of silica and alumina required to support the pozzolanic reaction in clay soils is relatively low.

\section{CONCLUSION}

The study was undertaken to study the physical and mechanical behaviour of silt dredged from the Fergoug dam treated with lime as a substitute for tuff to use in road earthworks.

The parameters studied are multiple and varied, including the percentages of constituents (sediment + lime), the method of samples preparation as well as the characteristics of each test. At the end of this study, we can draw the following main results:

- The addition of lime leads to an improvement in consistency because of a significant reduction in the plasticity index. The specific surface is reduced immediately after the incorporation of lime at the end of the clay's flocculation.

- The value of methylene blue index decreases with the addition of lime.

- The addition of lime to mixtures increases their optimal water content and reduces their maximum dry density.

- The lift of the mixture of (2\% lime + $(20 \%$ FDS + $80 \%$ SCT) ) is more to that ( $20 \% \mathrm{FDS}+80 \%$ SCT) for about $68 \%$, which explains the positive effect of the addition of lime

- The combination (2\% lime + (20\% FDS + 80\% SCT) is ideal to significantly improve the geotechnical properties of the studied silt; always for this same combination the compressive strength at 28 days is 3 times more than the untreated mixture value;

- The addition of lime improves compressive and punching resistance. This improvement is even more significant with the cure and it can be attributed to the filler

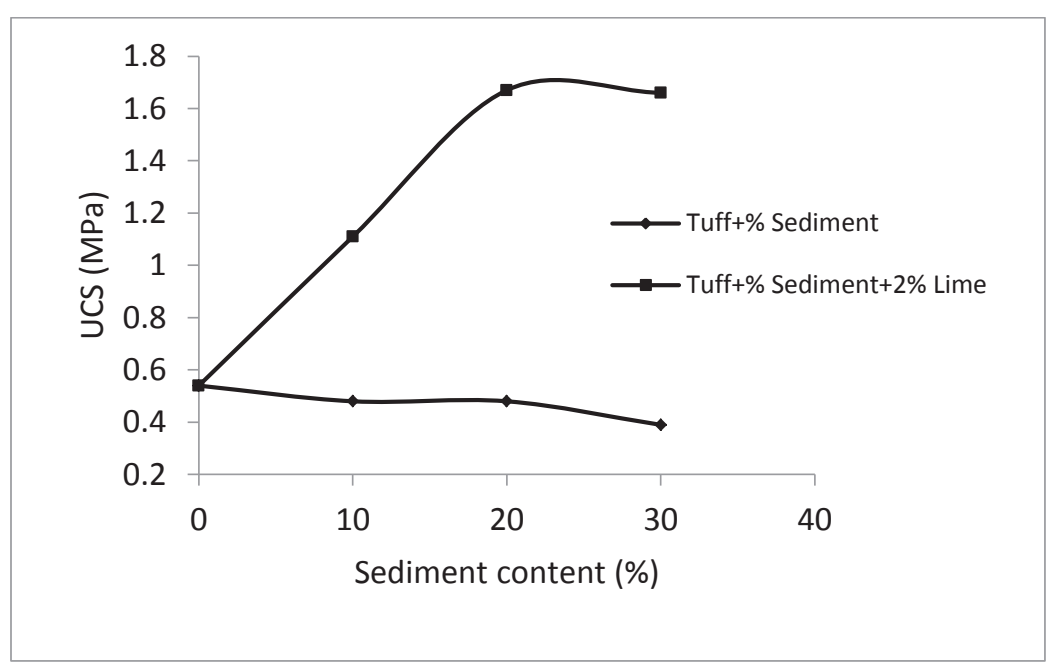

Fig. 12: Evolution of the UCS as a function of the sediment content (after treatment). 
effect due to its specific surface and the formation of the $\mathrm{C}-\mathrm{S}-\mathrm{H}$ gels due to the pozzolanic reaction. So, there is a creation of cementation of the soil particles which allows the increase of the resistance.

- The effectiveness of natural silt in the stabilization of soil/lime is thus acquired and we can use it in the field of roads construction.

\section{REFERENCES}

ANBT (Agence Nationale des Barrages et Transferts) 2014. Rapport annuel d'activité sur l'état des barrages Algériens. Kouba, Algeria,

Ansary, M.A., Noor, M.A. and Islam, M. 2006. Effect of fly ash stabilization on geotechnical properties of Chittagong coastal soil. In: Soil Stressstrain Behavior: Measurement, Modeling and Analysis, pp. 443-454. Springer, Dordrecht.

Attoh-Okine, N.O. 1995. Lime treatment of laterite soils and gravels-revisited. Construction and Building Materials, 9: 283-287.

Bell, F.G. 1996. Lime stabilization of clay minerals and soils. Engineering Geology, 42: 223-237.

George, S.Z., Ponniah, D.A. and Little, J.A. 1992. Effect of temperature on lime-soil stabilization. Construction and Building Materials, 6(4): 247-252.

GTR 2000. Guide technique pour la réalisation des remblais et des couches de forme. Fascicule I, principes généraux, LCPC-SETRA 100 pages.

GTS 2000. Traitement des sols à la chaux et aux liants hydrauliques-Guide technique. LCPC-SETRA, 240 pages.

Guney, Y., Sari, D., Cetin, M. and Tuncan, M. 2007. Impact of cyclic wetting-drying on swelling behavior of lime-stabilized soil. Building and Environment, 42: 681-688.

Hossain, K.M.A., Lachemi, M. and Easa, S. 2007. Stabilized soils for construction applications incorporating natural resources of Papua New Guinea. Resources, Conservation and Recycling, 51: 711-731.

Kavak, A. and Akyarh, A. 2007. A field application for lime stabilization. Environment Geology.51: 987-997.

Laoufi, L., Senhadji, Y. and Benazzouk, A. 2016. Valorisation of mud from Fergoug dam in manufacturing mortars. Case Studies in Construction Materials. 5: 26-38. http://dx.doi.org/10.1016/j.cscm.2016.06.002 2.
Larouci, A., Senhadji, Y., Laoufi, L. and Benazzouk, A. 2017. Valorisation de la vase du barrage de Fergoug pour une construction routière. $3^{\text {rd }}$ International Symposium on Materials and Sustainable Development (ISMSD2017). Boumerdès, Algérie.

Larouci. A., Senhadji, Y., Laoufi, L. and Benazzouk, A. 2018. Improvement of the mechanical performance of Fergoug dam sediments treated for reuse in road engineering. MATEC Web of Conferences 149, 01031, https://doi.org/10.1051/matecconf/201814901031.

Levacher, D., Colin, D., Perroni, A.C., Duan, Z. and Sun L. 2006. Recyclage et valorisation de sédiments fins de dragage à usage de matériaux routiers. IXème Journées Nationales Génie Civil- Génie Côtier, Brest, France, pp. 603-612.

Levacher, D., Sanchez, M., Duan, Z. and Liang, Y. 2011. Valorisation en unité pilote de sédiments méditerranéens: étude des caractéristiques géotechniques et de la perméabilité. Revue Paralia, 4 : 4.1-4.20, doi: 10.5150/revue-paralia.2011.004.

Manassah, J. and Olufemi, A.T. 2008. Effect of lime on some geotechnical properties of Igumale Shale. EJGE, 13.

Mellal, F. 2010. Etude du comportement physicochimique et mécanique d'un remblai routier marneux amélioré par la chaux éteinte, cas de l'autoroute Est-Ouest tronçon Oued Fodda /Khemis Miliana. Chlef : Thèse, Université Hassiba Benbouali de Chlef, Algérie.

Okagbue, C. O. and Ochulor, O. H. 2007. The potential of cement-stabilized coal-reject as a construction material. Bulletin of Engineering Geology and Environment, 66: 143-151.

Ola, S. A. 1977. The potentials of lime stabilization of lateritic soils. Eng. Geol., 11(4): 305-317.

Osinubi, K.J. 2006. Influence of compactive efforts on lime-slag treated tropical black clay. Journal of Materials in Civil Engineering, 18(2): 175-181.

Sakr, M.A., Shahin, M.A. and Metwally, Y.M. 2008. Utilization of lime for stabilizing soft clay soil of high organic content. Geotechnical Geology Engineering, 27(1): 105.

Sannier, L., Levacher, D. and Jourdan, M. 2009. Approche économique et validation de méthodes de traitements aux liants hydrauliques de sédiments marins contaminés. Revue Paralia, 2: s2.1-s2.15. doi:10.5150/ revue-paralia.2009.s02.

Semcha, A. 2006. Etude des propriétés géomécaniques des sédiments d'envasement de barrage et leur valorisation. Thèse de doctorat à l'université des sciences et de la technologie d'Oran, Algérie. 